\title{
THE INTENSITY AND THE STRUCTURE OF THE CROSS-BORDER TRAFFIC AT THE EASTERN BOUNDARY OF POLAND ON THE BASIS OF A FIELD STUDY
}

\author{
RAFAŁ WIŚNIEWSKI \\ Institute of Geography and Spatial Organization \\ Polish Academy of Sciences \\ Twarda 51/55, 00-818 Warszawa, Poland \\ e-mail: rafwis@twarda.pan.pl
}

\begin{abstract}
On the basis of data, collected by the Border Guards, it is not possible to determine the detailed geographical structure of vehicle traffic (passenger cars, heavy loads and coaches) crossing the eastern boundary of Poland. The sole source of information on the origin of the vehicles, coming to Poland, is constituted by the field studies. On the basis of such studies, carried out at five border crossing points (with Russia, Kaliningrad district, Belarus and Ukraine) detailed analysis was performed of the traffic of vehicles at the level of counties in Poland and districts in the countries, bordering upon Poland from the East. Key words: structure of cross-border traffic, border crossing points, field study, eastern border of Poland
\end{abstract}

\section{INTRODUCTION}

Over the entire post-war period, until 1989, the eastern boundary of Poland was characterised by a low degree of permeability (Komornicki 2008 b). The systemic and economic transformations brought about the changes in regulations and, in principle, complete opening of the boundaries. It was only in 2003 that Poland, in the pre-accession period to the European Union, introduced visa obligations for the citizens of, in particular, Belarus, Russia and Ukraine. The consecutive sharpening of the visa regime took place in 2007, after Poland joined the Schengen zone, which entailed the change of principles of crossing and protection of the eastern boundary of Poland.

The successive transformations of the function and the permeability of the boundary with Russia (the Kaliningrad district), Belarus and Ukraine, caused significant 
changes in the magnitudes of traffic of persons across the individual segments of the boundary. The magnitude of the traffic of persons was influenced, in particular, by the important differences of prices of goods (Powęska 2002), the purposeful policies of the eastern neighbours of Poland (mainly of Belarus), the international situation after 2001 (Komornicki 2008 a, b), or the previously mentioned introduction of visas by Poland before the accession to the EU. The structure of the cross-border traffic changed, as well, which was especially visible after 2003 and 2007 at the segment of the border with Ukraine, this country not having introduced the visa obligation for Poles. This brought about a reversal of the situation from before 2003, when the passenger traffic across the Polish-Ukrainian border had been dominated by the foreigners, while after 2003 an abrupt increase of the number of Poles, travelling to Ukraine, took place, mainly aiming at purchasing the goods that are encompassed by the excise tax in Poland (Komornicki 2008 b; Szejgiec and Wisniewski 2008). An analogous situation was observed at the border of Poland with the Kaliningrad district (Palmowski 2008), while the domination of foreigners persisted at the border with Belarus.

The statistical data, collected by the Border Guards, concerning the magnitude and the structure of the cross-border traffic, even though quite detailed (as containing, in particular, the information on the passenger and vehicle traffic according to particular border crossing points) do not allow for analysing the structure of the cross-border traffic on a micro-scale, e.g. with respect to counties. Determination of the approximate spatial reach of influence of a given border crossing is possible only on the basis of own investigations.

\section{METHODOLOGY OF THE FIELD STUDY}

The data, originating from the field study, which constituted the complement to the statistical data, collected by the Border Guards, made it possible to identify the geographical location of origin of the vehicles, crossing the boundary of Poland. The study concerned the structure of the cross-border traffic at selected border crossings along the eastern boundary of Poland. Five border crossing points were chosen for the study: Dorohusk and Zosin at the segment of the boundary with Ukraine, Bobrowniki and Połowce at the segment of the border with Belarus, and Gronowo at the border with Russia (the district of Kaliningrad), accounting for the functions fulfilled (full-fledged and local crossing points), and the magnitude of traffic through the crossings.

The field study consisted in recording of the fragments of license plates (territorial designations) of all the vehicles (passenger cars, trucks, coaches ${ }^{1}$ ) entering Poland. The timing of the study was selected in such a way as to account for both weekdays and holidays, in order to grasp the complete image of the magnitude of cross-bor-

${ }^{1}$ Motorcycles were treated as passenger cars. Only larger vans were treated as proper trucks, all the smaller ones (like, e.g. Citroen Berlingo), as well as the small busses and all-terrain cars were recorded as passenger cars. Other types of vehicles (e.g. road construction machines) were classified in the study as trucks. In the case of cars, pulling a trailer, the registration plate of the pulling car, and not that of the trailer, was recorded. 
der traffic. The study was carried out on June 12-15, 2008, between 8:00 a.m. and 8:00 p.m., without any break. All the kinds of the currently valid license plates were accounted for, i.e.:

- license plates issued in the years 1976-2000 (black, with white signs, that is-the registration system corresponding to the administrative breakdown of Poland into 49 voivodships), and

- license plates issued in the years 2000-2006 and then since 2006 (white with black signs, according to the new administrative breakdown).

Likewise, in the cases of Russian Federation, Belarus and Ukraine, all kinds of currently valid registration plates of vehicles were accounted for.

The study conducted allowed for the identification of the geographical location of the place, where the vehicle was registered, at the level of counties for Poland, and at the level of districts for the Russian Federation, Belarus and Ukraine. In case of vehicles from other countries only the international designation of the country, in which the given vehicle had been registered, was recorded.

During four days of the field study, over all the five border crossings the passing of altogether 7,758 vehicles was observed, out of which the vehicles with Polish license plates accounted for $62.0 \%$. This share displays a significant differentiation among the border crossing points, ranging from $32.8 \%$ in Bobrowniki to $82.4 \%$ in Zosin. This is the consequence of, in particular, the character of the crossing point (international or local), economic differentials between the two sides of the border (cross-border trade), as well as the formal regulations in force between Poland and Russia, Belarus and Ukraine. On the basis of data from the Border Guards on the magnitude of cross-border traffic on 12-15 June 2008 at the border crossing points considered, the magnitude of the sample investigated could be assessed (Table 1).

Table 1 . The magnitude of the border traffic on June 12-15, 2008, according to the data from the Border Guards and the field study

\begin{tabular}{|c|c|c|c|c|c|}
\hline \multirow{2}{*}{$\begin{array}{l}\text { Border } \\
\text { crossing }\end{array}$} & \multicolumn{3}{|c|}{$\begin{array}{l}\text { Magnitude of the (incoming) vehicle } \\
\text { traffic according to the field study. } \\
\text { Numbers of vehicles }\end{array}$} & \multirow{2}{*}{$\begin{array}{l}\text { Magnitude } \\
\text { of traffic of } \\
\text { vehicles on } \\
\text { the basis of } \\
\text { data from the } \\
\text { Border Guards. } \\
\text { Numbers of } \\
\text { vehicles }\end{array}$} & \multirow{2}{*}{$\begin{array}{c}\text { Sample } \\
\text { share }\end{array}$} \\
\hline & $\begin{array}{l}\text { with Polish } \\
\text { registration }\end{array}$ & $\begin{array}{l}\text { with foreign } \\
\text { registration }\end{array}$ & totals & & \\
\hline Gronowo & 536 & 484 & 1047 & 1595 & $65.6 \%$ \\
\hline Bobrowniki & 306 & 627 & 933 & 2221 & $42.0 \%$ \\
\hline Połowce & 747 & 265 & 1012 & 1594 & $63.5 \%$ \\
\hline Dorohusk & 1732 & 1263 & 2995 & 3811 & $78.6 \%$ \\
\hline Zosin & 1459 & 312 & 1771 & 3751 & $47.2 \%$ \\
\hline Totals & 4807 & 2951 & 7758 & 12972 & $59.8 \%$ \\
\hline
\end{tabular}

Source: own elaboration on the basis of data from the Border Guards and the field study. 
Thus, the total number of vehicles, entering Poland, which were recorded over the four days of the field study, constituted almost $60 \%$ of the entire traffic. The share of the sample differs significantly among the border crossing points. The lowest share was observed in Bobrowniki, which is, in particular, due to the fact that an important part of the traffic of heavy loads took place during the night time, when field study was not conducted ${ }^{2}$.

It ought to be emphasised that the field study was conducted with awareness of definite imprecision, resulting from the adopted method of data collection. With respect to (private) passenger cars it can be assumed that the location of registration of the vehicle, determined on the basis of license plates (i.e. counties in Poland and districts in the neighbouring countries) are actually the origins of the movements realised. Hence, on this basis it is possible to determine the geographical structure of the passenger car traffic. On the other hand, analogous conclusions concerning the heavy load cars must be formulated with great care. First, the places of registration of the truck tractor and the trailer may differ ${ }^{3}$. Second, the location of registration of a vehicle does not have to correspond to the actual origin of the trip. It appears that in view of the character of this kind of transport activity this may depend upon the spatial distribution of the forwarding companies. It can be expected, though, that in the spatial analysis carried out for provinces or districts this ought not have a bigger significance for the correctness of the conclusions formulated.

\section{CHARACTERISATION OF THE BORDER TRAFFIC IN GRONOWO}

Border crossing Gronowo-Mamonovo is fit for the traffic of all kinds of vehicles (passenger and heavy load cars, coaches). During the field study altogether 1,047 vehicles, entering Poland from the area of the Kaliningrad district were recorded (Table 2), with more than $91 \%$ of this number corresponding to passenger cars.

Table 1. The magnitude of the border traffic on June 12-15, 2008, according to the data from the Border Guards and the field study

\begin{tabular}{|c|c|c|c|c|}
\hline \multirow{2}{*}{$\begin{array}{c}\text { Nature of } \\
\text { vehicle }\end{array}$} & \multicolumn{3}{|c|}{ Number of vehicles } & \multirow{2}{*}{ Totals } \\
\cline { 2 - 4 } & Poland & Russia & other countries & \\
\hline Passenger cars & 556 & 358 & 45 & 959 \\
\hline Trucks & 3 & 61 & 2 & 66 \\
\hline Coaches & 4 & 15 & 3 & 22 \\
\hline Totals & 563 & 434 & 50 & 1047 \\
\hline
\end{tabular}

Source: own elaboration on the basis of data from the Border Guards and the field study.

\footnotetext{
2 The share of the sample with respect to passenger and heavy load cars at the crossing in Bobrowniki amounted to, respectively, $55.2 \%$ and $28.5 \%$.

${ }^{3}$ Location of registration of the truck tractor was recorded in the study.
} 
In the geographical structure the vehicles registered in Poland dominate (53.8\%), followed by those from Russia (41.5\%, mainly from the Kaliningrad district-the share of the remaining administrative units of the Russian Federation amounts to less than $1 \%)$. The share of registrations from other countries is low (4.8\%), and in this group a decisive domination of cars registered in Germany was observed (79.2\%). The geographical structure differs distinctly among the different kinds of vehicles. Thus, with respect to passenger cars there is a clear domination of vehicles from Poland (58.0\%), with those from Russia accounting for 37.3\%. On the other hand, the heavy load traffic is dominated by the vehicles from the Kaliningrad district, whose share in the total number of trucks entering Poland amounted to more than $92 \%$. As it could be expected, only a minor part of goods exported from the Russian Federation goes through the Kaliningrad district. Among the coaches there is also a clear domination of those registered in the Kaliningrad district (68.2\%), with those from Poland accounting for $18.2 \%$ of the total, and from the remaining countries-for $13.6 \%$.

In terms of more detailed geographical distribution of the locations of registration for the vehicles with Polish license plates the study showed that a distinct majority of them $(82.6 \%)$ originated from the Warmian-Masurian province, where Gronowo is situated, and mainly from the border-adjacent counties, i.e. Braniewo, Elblag and the town of Elblagg itself (see Figure 1). More than $14 \%$ of vehicles had license plates from the neighbouring Pomeranian province (counties of Malbork, Kwidzyn and Sztum). Hence, we deal with a local traffic, oriented at profiting from the peri-border trade (fuel, alcohol, cigarettes). There are also frequent trips of the Russians, especially during various holidays, with the aim of bringing used cars, mainly from Germany 4 .

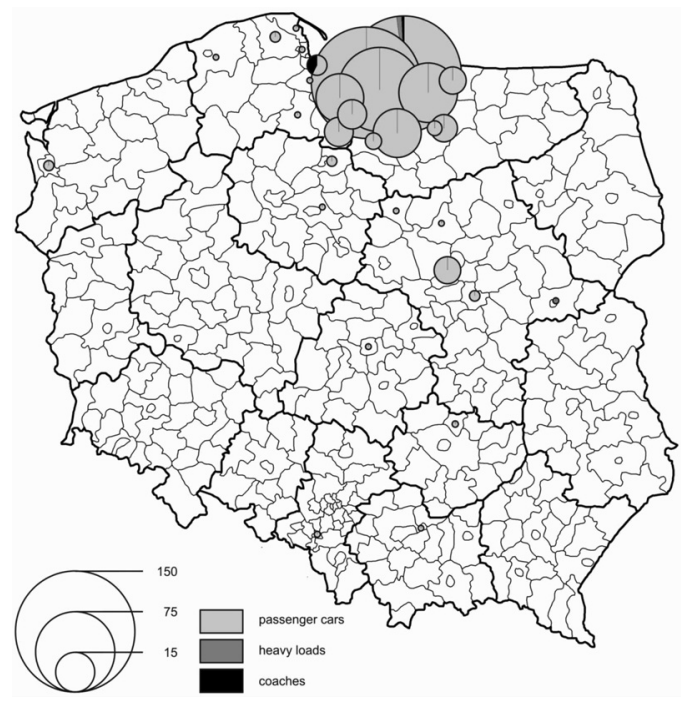

Figure 1. Geographical structure of the cross-border traffic in Gronowo (vehicles from Poland) Source: Figures 1-5 own elaboration on the basis of field study.

${ }^{4}$ An increase in the intensity of traffic of vehicles pulling car-carriages was observed during weekends. 


\section{CHARACTERISATION OF THE BORDER TRAFFIC IN BOBROWNIKI}

Border crossing in Bobrowniki ranks the third in terms of intensity of traffic (following Terespol and Kuźnica) along the border with Belarus. During the field study 933 vehicles entering Poland were observed at this border crossing (Table 3). This was the sole border crossing point, included in the study, where more vehicles with foreign license plates were observed than with the Polish ones. Passenger cars accounted for $66.3 \%$ of total traffic of vehicles.

Table 3. Magnitude of the cross-border traffic at the crossing in Bobrowniki

\begin{tabular}{|c|c|c|c|c|}
\hline \multirow{2}{*}{$\begin{array}{c}\text { Nature of } \\
\text { vehicle }\end{array}$} & \multicolumn{3}{|c|}{ Number of vehicles } & \multirow{2}{*}{ Totals } \\
\cline { 2 - 4 } & Poland & Belarus & other countries & \\
\hline Passenger cars & 271 & 330 & 18 & 619 \\
\hline Heavy loads & 34 & 131 & 148 & 313 \\
\hline Coaches & 1 & 0 & 0 & 1 \\
\hline Totals & 306 & 461 & 166 & 933 \\
\hline
\end{tabular}

Source: own elaboration on the basis of data from the Border Guards and the field study.

As mentioned already before, cars with foreign registrations dominate in this traffic $(67.2 \%)$, mainly those from Belarus and Russia, which account for as much as $97.3 \%$ of the total of vehicles registered abroad. While among the passenger cars with foreign registrations an overwhelming majority come from Belarus (94.8\%), in the case of trucks there is a slight domination of the ones with Russian registration $(50.2 \%)$.

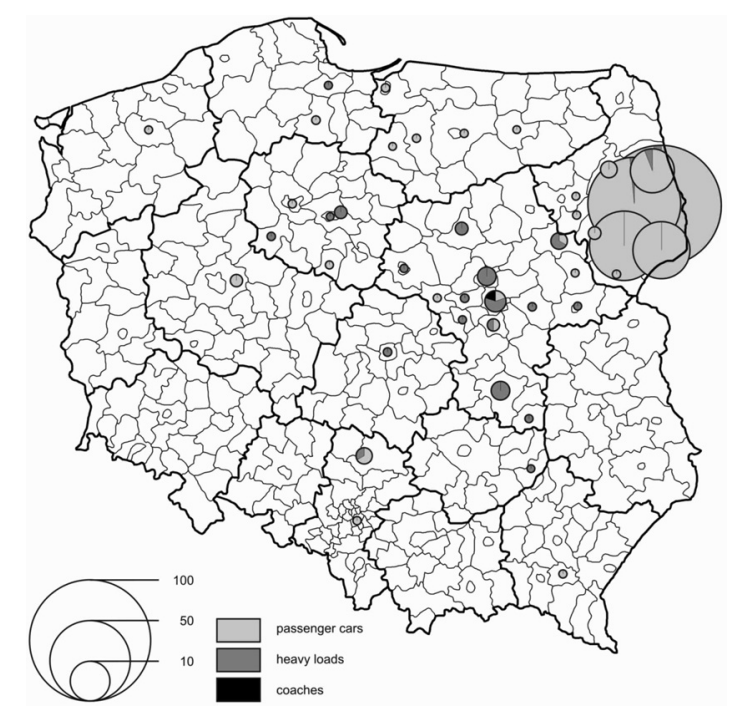

Figure 2 b. Geographical structure of the cross-border traffic in Bobrowniki (vehicles from Belarus) 


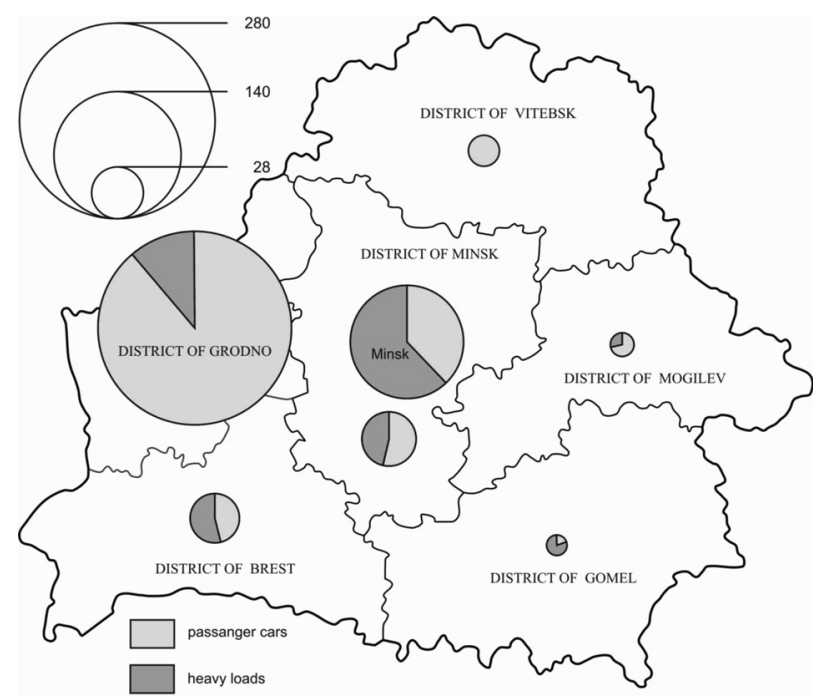

Figure 2 a. Geographical structure of the cross-border traffic in Bobrowniki (vehicles from Poland)

Similarly as in the case of geographical structure of the cross-border traffic at the crossing in Gronowo, also in Bobrowniki, among the vehicles with Polish license plates, the ones originating from the border-adjacent areas form a clear majority. More than $83 \%$ of the Polish cross-border traffic is constituted by the vehicles registered in the provinces of Podlasie, mainly in the county of Białystok (the city and the landed county), as well as in the counties of Bielsk Podlaski, Hajnówka and Sokółka (Figure 2 a).

Table 4. Geographical structure of the incoming traffic of the Russian heavy loads at Gronowo

\begin{tabular}{|l|c|c|}
\hline \multicolumn{1}{|c|}{ Administrative unit } & Number of trucks & Percentage share \\
\hline Moscow & 40 & 28.6 \\
\hline Sankt Petersburg & 21 & 15.0 \\
\hline District of Brian'sk & 20 & 14.3 \\
\hline District of Moscow & 17 & 12.1 \\
\hline District of Kaliningrad & 12 & 8.6 \\
\hline District of Smolensk & 11 & 7.9 \\
\hline District of Kaluga & 10 & 7.1 \\
\hline Land of Perm & 4 & 2.9 \\
\hline District of Samara & 3 & 2.1 \\
\hline District of Pskov & 1 & 0.7 \\
\hline District of Kostroma & 1 & 0.7 \\
\hline Totals & 140 & 100.0 \\
\hline
\end{tabular}

Source: own elaboration on the basis of data from the Border Guards and the field study. 
The traffic of the Belarusian vehicles is generated mainly by the ones registered in the Grodno (Hrodna) district (59.4\%), followed by the city of Minsk (23.4\%), the district of Minsk (6.5\%) and the district of Brest (5.6\%). Among the passenger cars their highest number originated from the district of Grodno, but in the case of heavy loads more than half were the vehicles registered in Minsk (Figure $2 \mathrm{~b}$ ). Close to $57 \%$ of all the vehicles, entering Poland, were registered in the administrative units adjacent to the border, which might constitute an evidence for the local character of these movements, associated primarily with the peri-border trade. In view of the intensive traffic of the Russian trucks their origins, according to districts, in which they had been registered, is shown in Table 4.

\section{CHARACTERISATION OF THE CROSS-BORDER TRAFFIC IN POŁOWCE}

Border crossing Połowce-Pieszczatka on the Polish-Belarusian border is prepared only for passenger traffic and is open solely for the citizens of Poland and Belarus ${ }^{5}$. It has, therefore, a strongly local nature, resulting from the formal-administrative regulations.

During the field study 1,012 vehicles crossed the border, coming to Poland. A decisive majority of the traffic was constituted by the vehicles, registered on the territory of Poland (73.8\%, 747 vehicles). As demonstrated by the study, the border crossing in Połowce is being made use of by the persons, whose cars are registered in the province of Podlasie (99.5\%)—Figure 3 a. Cars from the county of Hajnówka, where the border crossing is located, dominate (43.8\% of the Polish cross-border traffic). High shares in this traffic take also the vehicles registered in the counties of Bielsk Podlaski (37.6\%) and Siemiatycze (15.1\%).

The traffic of the vehicles, registered in Belarus (altogether 265 of them) is mostly generated by the cars registered in the district of Brest (94.0\%)-Figure $3 \mathrm{~b}$. Besides, individual cases were observed of the cars registered in the districts of Vitebsk (9 vehicles), Grodno (4), Gomel (1), and Minsk (1), as well as in the city of Minsk (1).

The majority of persons, making use of the border crossing in Połowce, deal with the petty cross-border trade, which sometimes takes organised forms. During the field study the cases were observed, in which the same vehicle crossed the border several times over. Poles are primarily interested in purchasing fuel, while the Belarusians are interested, in particular, in food and chemical products.

\footnotetext{
5 Extension of the border crossing in Połowce and making it available for the international traffic is planned. After the termination of this project the border crossing is meant to be available for the passenger cars and for trucks of up to 7.5 tonnes of capacity.
} 


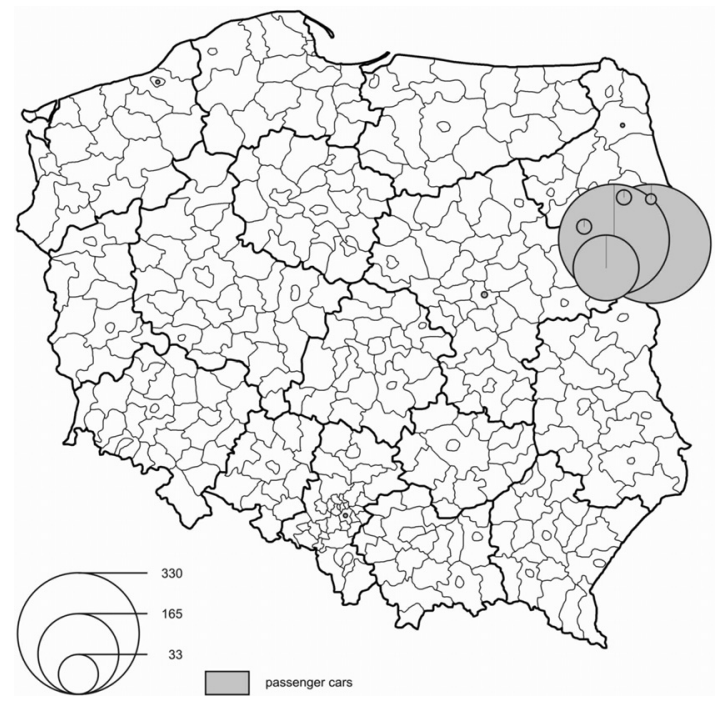

Figure 3 a. Geographical structure of the cross-border traffic in Połowce (vehicles from Poland)

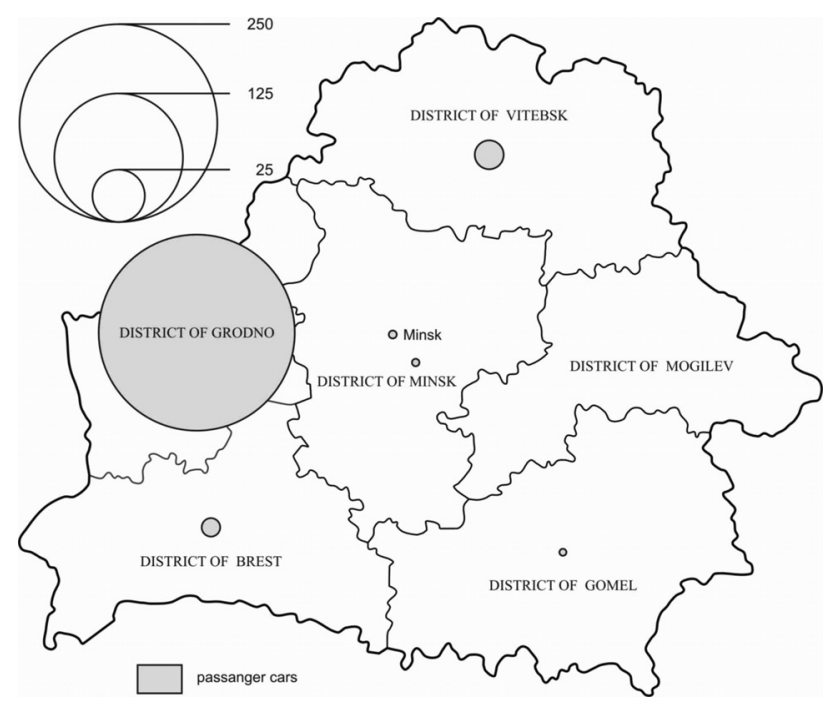

Figure 3 b. Geographical structure of the cross-border traffic in Połowce (vehicles from Belarus)

\section{CHARACTERISATION OF THE CROSS-BORDER TRAFFIC IN DOROHUSK}

During the four days of the field study, altogether 2,995 vehicles were observed, crossing the Polish-Ukrainian border at the road border crossing point in Dorohusk, of which a large majority (around $71.5 \%$ ) were passenger cars (see Table 5). 
In the geographical structure of the border traffic the vehicles registered in Poland dominate $(57.8 \%)$, followed by the Ukrainian ones $(38.4 \%)$, with the remaining countries (mainly Germany, Lithuania and Latvia) accounting for less than $4 \%$ of the entire traffic. Yet, these shares differ for the particular kinds of vehicles. As far as passenger cars are concerned, those with Polish license plates dominate clearly $(64.7 \%)$, while the share of the Ukrainian cars is at $33.4 \%$. In the case of heavy loads the shares of the two countries are balanced (Ukraine 49.6\%, Poland 47.0\%, remaining countries $3.1 \%$ ). In the coach traffic there is a clear majority of those registered in Ukraine (71.1\%). Coaches registered in Poland account for $17.8 \%$ of this traffic, while those registered in other countries- $8.9 \%$.

Table 5. Magnitude of the cross-border traffic at the border crossing in Dorohusk

\begin{tabular}{|c|c|c|c|c|}
\hline \multirow{2}{*}{$\begin{array}{c}\text { Nature of } \\
\text { vehicle }\end{array}$} & \multicolumn{3}{|c|}{ Number of vehicles } & \multirow{2}{*}{ Totals } \\
\cline { 2 - 4 } & Poland & Ukraine & other countries & \\
\hline Passenger cars & 1346 & 715 & 81 & 2142 \\
\hline Heavy loads & 381 & 401 & 29 & 811 \\
\hline Coaches & 5 & 33 & 4 & 42 \\
\hline Totals & 1732 & 1149 & 114 & 2995 \\
\hline
\end{tabular}

Source: own elaboration on the basis of data from the Border Guards and the field study.

The biggest number of vehicles originate from the border-adjacent areas: in Poland-from the province of Lublin, and in Ukraine from the district of Volhynia, but also from Kiev. Spatial differentiation of the locations of vehicle registration in the setting of counties is as follows: side by side with the dominating border-adjacent counties (the town and the landed county of Chełm, county of Włodawa), from which a decisive majority of vehicles originates, one observes high numbers of vehicles registered in the counties, located quite far from the border crossing in Dorohusk, for instance-in the county of Bielsk Podlaski (both landed and town counties), Łuków, Radzyń, Lublin, and even Łosice, Siedlce, as well as Radom, Warsaw and Poznań (Fig. 4a). Only few vehicles originated from the southern counties of the province of Lublin, this fact being associated with the influence of the local border crossing in Zosin. Such an effect, on the other hand, does not appear in the northern part of the province, where two border crossings with Belarus are located (Sławatycze and Terespol). The majority of the traffic at the border crossing in Dorohusk is constituted by the local movements, associated with the periborder trade activity. The scale of this phenomenon at the Polish-Belarusian border is limited in comparison with the Polish-Ukrainian border, due, in particular, to formal reasons (visa formalities obligatory for both sides).

Geographical distribution of the locations of passenger car registration for the cars from Poland coincides with the geographical distribution of vehicles in general. On the other hand, in case of trucks, bigger spatial differentiation can be observed. The highest number of heavy loads, crossing the border in Dorohusk, 


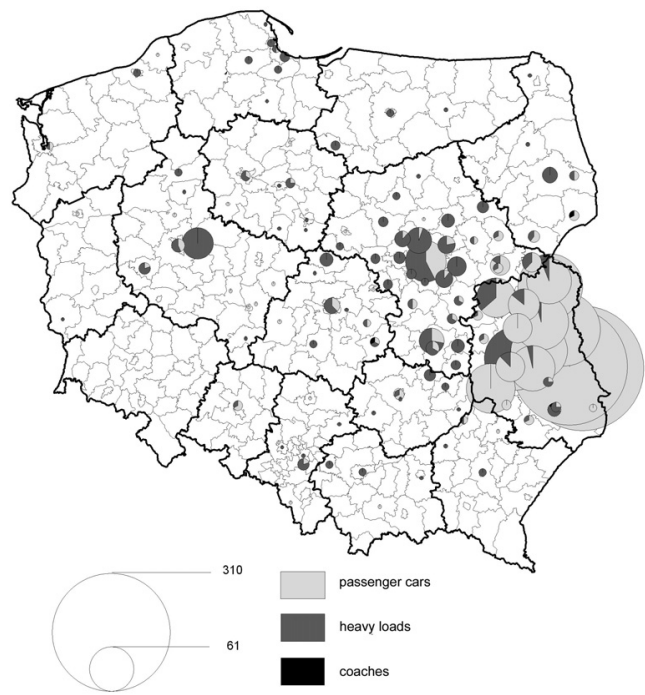

Figure 4 a. Geographical structure of the cross-border traffic in Dorohusk (vehicles from Poland)

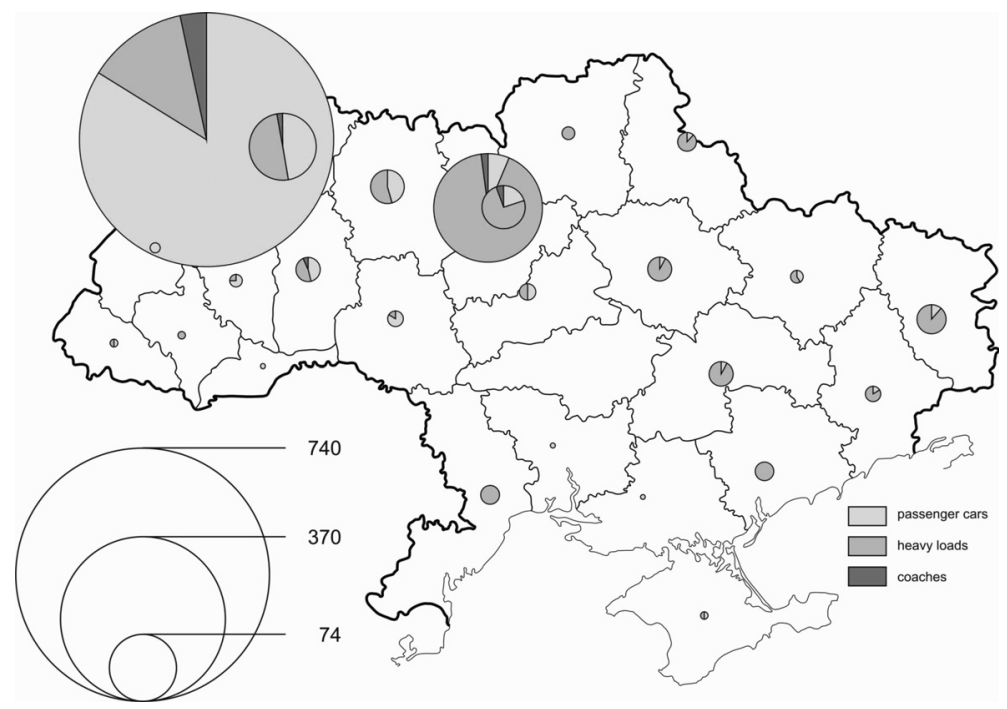

Figure 4 b. Geographical structure of the cross-border traffic in Dorohusk (vehicles from Ukraine)

came from Lublin, then from Poznań, Warsaw, and from the counties of Legionowo and Łuków. In the setting of provinces the highest number came from the province of Masovia (40.9\%), then from the province of Lublin (24.4\%) and Wielkopolska $(8.9 \%)$. The traffic of the Ukrainian trucks is generated primarily by the vehicles originating from the district of Volhynia (86.4\%). In the case of trucks one can notice significant spatial differentiation of the locations of their registration, 
although the intensity of traffic from the majority of districts is relatively low. Vehicles registered in the city of Kiev and in district of Kiev (42.0\%), along with those from the districts of Volhynia (23.9\%) and Rivne (9.0\%) dominate, see Figure 4 b.

From among the other countries the vehicles registered in Germany dominate (mainly passenger cars), accounting for $33.7 \%$ of traffic from the remaining countries. There is also a high share of vehicles from the Baltic countries (altogether $42.3 \%$ ), of which almost half were trucks, which travel through the territory of Poland and circumvent Belarus (faster overall travel and lack of visa formalities).

\section{CHARACTERISATION OF THE CROSS-BORDER TRAFFIC IN ZOSIN}

During the field study, at the border crossing in Zosin altogether 1,771 vehicles, entering Poland, were observed, of which $99.5 \%$ were passenger cars, while the remaining ones were coaches (Table 6).

Table 6. Magnitude of the cross-border traffic at the border crossing in Zosin

\begin{tabular}{|c|c|c|c|c|}
\hline \multirow{2}{*}{$\begin{array}{c}\text { Nature } \\
\text { of vehicle }\end{array}$} & \multicolumn{3}{|c|}{ Number of vehicles } & \multirow{2}{*}{ Totals } \\
\cline { 2 - 4 } & Poland & Ukraine & remaining countries & \\
\hline Passenger cars & 1451 & 277 & 35 & 1763 \\
\hline Coaches & 8 & 0 & 0 & 8 \\
\hline Totals & 1459 & 277 & 35 & 1771 \\
\hline
\end{tabular}

Source: own elaboration on the basis of data from the Border Guards and the field study.

The geographical structure was dominated by the vehicles from Poland $(82.4 \%)$, with the Ukrainian vehicles accounting for close to $16 \%$ of the total, and those from the remaining countries-not quite $2 \%$.

Among the observed vehicles with Polish registration an overwhelming majority originated from the Lublin province (79.2\%), demonstrating very high spatial concentration of traffic at this border crossing. The field study demonstrated also that the traffic at this border crossing is created first of all by the inhabitants of Hrubieszów county $(34.0 \%)$, followed by those from the counties of Zamość (13.7\%), Krasnystaw (7.4\%), and the town of Zamość itself (5.8\%). Vehicles from outside of the Lublin province, among which the biggest number came from the province of Masovia, constituted only $3 \%$ of all the vehicles entering Poland (Figure 5 a).

The traffic of vehicles with Ukrainian registration plates originated mainly from the border-adjacent district of Volhynia (more than $3 / 4$ of all vehicles with Ukrainian registration plates), while the contribution of vehicles coming from the district of Rivne and from the city of Kiev to this traffic was very limited (Figure $5 \mathrm{~b}$ ). The border crossing in Zosin, similarly as that in Dorohusk, was to a very limited degree made use of by the citizens of other countries. Among the latter the biggest group was constituted by the Germans and the inhabitants of the Baltic countries (mainly Lithuania and Latvia). 


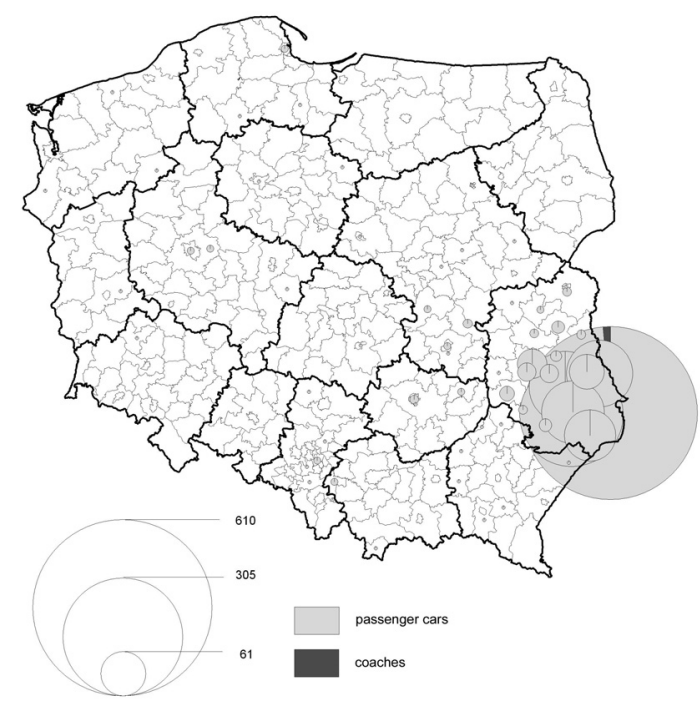

Figure 5 a. Geographical structure of the cross-border traffic in Zosin (vehicles from Poland)

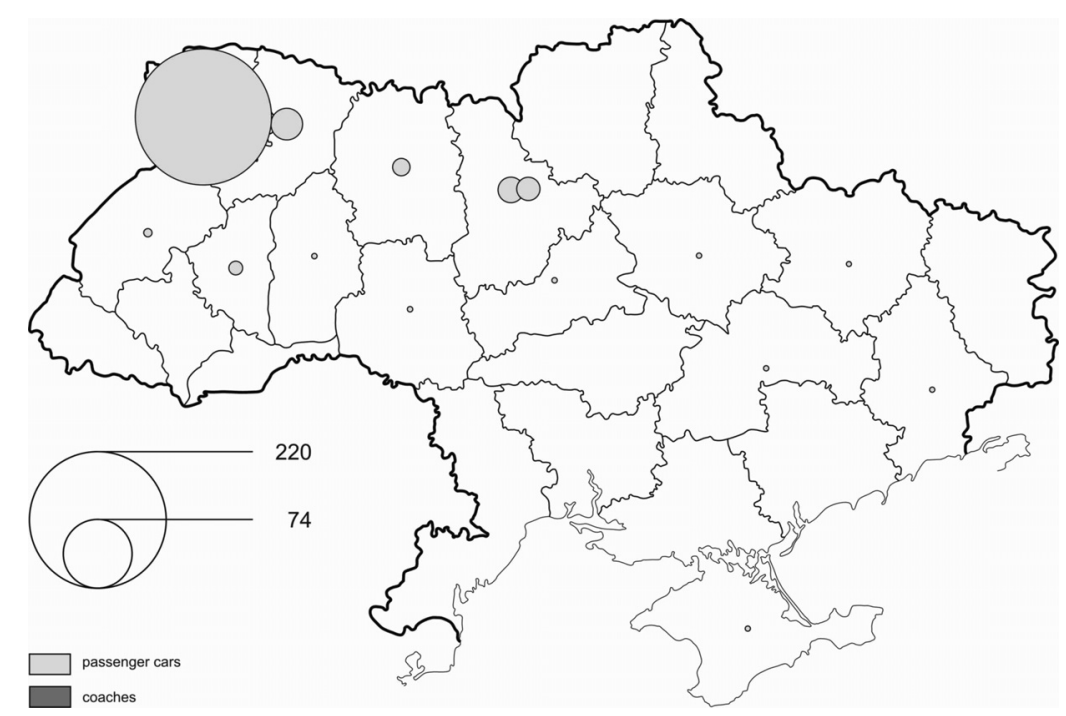

Figure 5 b. Geographical structure of the cross-border traffic in Zosin (vehicles from Ukraine)

\section{SUMMARY}

During the field study, conducted at selected border crossing points, located on the borders with Russia, Belarus and Ukraine, close to 7,800 various vehicles, entering Poland, were recorded, accounting for almost $60 \%$ of the total traffic, entering Poland during the period of study, through the selected crossing points. This traffic was 
dominated by the vehicles (mainly passenger cars), registered in Poland, in these administrative units, in which the respective border crossings were situated. At all the border crossings considered the traffic was dominated by the local movements of private persons, associated with the petty cross-border trade. In this case the beginnings and ends of the respective journeys were located within the areas relatively close to the state border. On the other hand, the traffic of trucks is linked primarily with the official trade between the countries involved and its spatial reach is decidedly bigger.

The eastern boundary of Poland constitutes a barrier, which separates the areas, featuring different levels of the socio-economic development. The possibilities of eliminating the influence of this barrier are very limited, unless a distinct change in geopolitical conditions takes place. In order to diminish the hardships, related to the crossing of the border, an agreement was signed, in particular, between Poland and Ukraine, concerning the local cross-border traffic, and signing of a similar agreement is planned for the Belarusian segment of the border zone. On the other hand, in the traffic across the border with the Kaliningrad district visas are required, but they are issued at no cost.

This, perhaps, is the attempt to resolve the dilemma of conciliating the internal regulations of community life within the European Union, and the associated necessity of tightening the outer boundaries, with the desire of maintaining good cooperation relations with the neighbouring countries across the eastern border.

\section{REFERENCES}

Komornicki, T. (2008 a), Granica polsko-białoruska jako bariera przestrzenna, in: Współczesne problemy badawcze geografii polskiej-geografia człowieka, Dokumentacja Geograficzna, 36, IGiPZ PAN, PTG, Warszawa, 55-61.

Komornicki, T. (2008 b), Polska granica wschodnia—zmiany w natężeniu, strukturze i kierunkach interakcji w latach 1990-2007, in: Dołzbłasz, S. and Raczyk, A. (eds.), Przekształcenia regionalnych struktur funkcjonalno-przestrzennych. Europa bez granic—nowa jakość przestrzeni, Rozprawy Naukowe Instytutu Geografii i Rozwoju Regionalnego Uniwersytetu Wrocławskiego, 4, Wrocław, 109-119.

Palmowski, T. (2008), Wybrane problemy pogranicza polsko-rosyjskiego po wprowadzeniu Układu z Schengen, in: Dołzbłasz, S. and Raczyk, A. (eds.), Przekształcenia regionalnych struktur funkcjonalno-przestrzennych. Europa bez granic—nowa jakość przestrzeni, Rozprawy Naukowe Instytutu Geografii i Rozwoju Regionalnego Uniwersytetu Wrocławskiego, 4, Wrocław, 131-139.

Powęska, H. (2002), Przestrzenny wymiar handlu transgranicznego w Polsce w ostatniej dekadzie XX wieku, Geopolitical Studies, 9, IGiPZ PAN, Warszawa.

Szejgiec, B., Wiśniewski, R. (2008), Struktura i wielkość ruchu granicznego na granicy polsko-ukraińskiej, in: Dołzbłasz, S. and Raczyk, A. (eds.), Przekształcenia regionalnych struktur funkcjonalno-przestrzennych. Europa bez granic-nowa jakość przestrzeni, Rozprawy Naukowe Instytutu Geografii i Rozwoju Regionalnego Uniwersytetu Wrocławskiego, 4, Wrocław, 121-129. 